\title{
Recent Case Law Of The Romanian Courts Of Law And The European Court Of Justice Related To The Objective Environmental Liability
}

\author{
${ }^{1,2}$ Cristian Mares, ${ }^{1}$ Constanta Mătusescu \\ ${ }^{1}$ Faculty of Law and Social - Political Sciences, "Valahia" \\ University of Târgoviste, Târgoviste, Romania \\ ${ }^{2}$ Attorney at law, Bucharest Bar Association \\ Bucharest, Romania
}

Received: May 5, 2019. Revised: June 5, 2021. Accepted: September 22, 2021. Published: November 25, 2021.

\begin{abstract}
Although the economic interests have played a major political role in the recent period, in a number of litigations the courts applied the "polluter pays" principle and rendered favorably judgments to the claimants which suffered a damage caused by pollution.

In this respect, it is worth analyzing the case law of the European Court of Justice which has recently provided the presumption of liability for pollution of the operators which operates installations on land adjacent to a polluted area.

As the Romanian case law is concerned, given the novelty of the framework of an objective environmental liability and the low number of cases related to this issue, it is to be developed a constant jurisprudence as the decision rendered by the Romanian Court of Appeal as of March 9, 2009, which forced a polluter to remedy totally and in kind the damage caused to an individual's house.
\end{abstract}

Keywords - objective liability, precautionary principle, "polluter pays" principle, prevention, remedying

\section{INTRODUCTION}

Considering that the guarantee of a high level of environmental protection is a major objective and being convinced that the existing systems of sanctions have not been sufficient to achieve complete compliance with laws for the protection of the environment, this paper intends to present the most relevant recent case law of the Romanian courts of law and of the European Court of Justice.

Romanian courts of law decided to force a polluter to rebuild an individual's house on another site, in an unpolluted area. According to this decision of the court, the right to a healthy environment is included in the article 8 of the European Convention of Human Rights (hereinafter "the European Convention"), given that the serious environmental damage can affect an individual who can be deprived of the right to have a dwelling which guarantees his right to private life, even if it does not endanger his health [1].

At European level, remedying the environmental damage is usually considered as one of the lacunae in the European Union environmental law. On March 9, 2010, the European Court of Justice in Luxembourg ruled on the implementation of the Directive 2004/35/CE on environmental liability with regard to the prevention and remedying of environmental damage (hereinafter "Environmental Liability Directive") [2] in the cases C-378/08, C-379/08 and C-380/08, opposing the Italian economy ministry and a refinery company. The European Court of Justice ruled that it is enough to establish the liability of the charged company given that it used a chemical that was also found at the damaged site.

The European Court of Justice decided that the national authorities have the right to presume "that there is a causal link between operators and the pollution found" close to their premises in case of evidence which may justify such presumption [3]. The case was handed over to the Court following the contestations submitted by several companies in the petrochemical and hydrocarbon sector against the orders for cleaning up nearby pollution under the "polluter pays" principle.

\section{CASE STUDIES}

\section{A. Romanian case law}

The Romanian courts recently ruled that the polluter's liability provided by the Government Emergency Ordinance no. 195/2005 regarding the environmental protection, as further amended and supplemented, is a particular form of the tort liability and comes of the obligation of protecting the environment imposed to all individuals and legal entities by article 94 letter i) [4].

According to the reasons of the decision no. 322 of the Court of Appeal of Craiova (hereinafter "the Court of Appeal"), this Government Emergency Ordinance provides that the polluter bears the cost for compensating the damage and restores the resulted consequences. Given that the environmental liability is objective, only the damage and the causal link must be proven.

The activities within the coal depot totally modified the environment and consequently the claimant's house was adversely affected, which was located at a distance of $50 \mathrm{~m}$ from the warehouse.

In 1994, the European Court of Human Rights decided for the first time that the right to a healthy environment is included in article 8 of the European Convention which 
provides everyone's right to respect for his private and family life [5].

In the case Lopez Ostra v. Spain, the European Court of Human Rights considered that Spain did not succeed in finding a balance between the general local interest of having a waste-treatment plant and the applicant's effective right to respect for her home and her private and family life.

The European Court of Human Rights stated that serious environmental pollution may affect a person's welfare and deprive him/her from enjoying his/her homes in such a way as to affect his/her private and family life even if it is not a severe hazard to the deprived person's health.

The Court of Appeal also considered the case Tătar v. Romania, where Romania was held responsible on the basis of article 8 of the European Convention, because the right to a healthy environment of both claimants was breached given the environmental impact of a cyanide technology used for exploitation of gold [6].

Following an accident which occurred in January 2000, a gold mine located in the vicinity of the applicants' home, released about $100,000 \mathrm{~m}^{3}$ of cyanide contaminated tailings water into the environment and it did not stop its activity after that accident. The applicants complained that (i) the mining activity was a health hazard for the people living near the mine; (ii) it posed a threat to the environment and (iii) it was aggravating their son's asthma.

Although the European Court of Human Rights decided that the applicants had failed to prove any causal link between their son's medical condition and his exposure to cyanide, the gold mine had breached the precautionary principle given that it continued its industrial activity after the accident.

The European Court of Human Rights ascertained that the Romanian authorities did not impose operating conditions to a company in order to avoid the damage to the environment and human health, breaching the precautionary principle which could have requested a restriction of the activity, given that there were serious doubts related to the safety of the technological process. According to the precautionary principle the absence of certainty regarding current scientific and technical knowledge could not justify any delay of the state in adopting proportionate and effective measures.

Another consideration of the Court of Appeal was that the state must take all reasonable and appropriate measures in order to protect the rights provided by the first paragraph of article 8 of the European Convention and, moreover, the obligation to create a legislative and administrative framework capable to prevent efficiently the damage to the environment and human health and, in case of hazardous activities, to consider the potential or actual risks. Such obligation is transposed in the authorization, the operation, the security and the control of the respective activity and also in imposing those who develop such activities the obligation to take all the necessary measures in order to ensure the effective protection of the citizens whose live risks to be affected by the specific threats of the activity.

Considering the above mentioned provisions, case law and the evidences produced in this litigation, the Romanian
Courts decided that the activities of the defendant breached the claimant's right to a healthy environment which is part of his right to private life, a damage occurred and must be remedied.

Therefore, the Court of Appeal decided that the first instance and the appeal Courts chose the correct remedial measure of the damage (to force the polluter to rebuild the individual's house on another site, in an unpolluted area), given that the damage must be remedied totally and in kind (the option of remedying by an equivalent is subsidiary).

\section{B. European Court of Justice case law}

In the case C-378/08, Tribunale amministrativo regionale della Sicilia (Italy), by its decision of June 5, 2008, made a reference in proceedings between Raffinerie Mediterranee (ERG) SpA, Polimeri Europa SpA and Syndial SpA and various national, regional and municipal authorities in Italy concerning the measures for remedying environmental damage adopted by those authorities in relation to the Augusta roadstead (Italy), in the vicinity of which are located the installations and/or land of those companies.

Tribunale amministrativo regionale della Sicilia referred the following questions to the European Court of Justice for a preliminary ruling:

- If the "polluter pays" principle and the provisions of the Environmental Liability Directive must be interpreted as they prevent national legislation which allows the public authorities to require private entities to implement rehabilitation measures, irrespective of any preliminary investigation identifying the party responsible for the pollution?

- If the "polluter pays" principle and the provisions of the Environmental Liability Directive must be interpreted as they prevent national legislation allowing the public authorities to establish liability for remedying the environmental damage to the person who owns and/or carries on commercial activities on the contaminated site without an assessment whether there is a causal link between the conduct of that person and the occurrence of the contamination?

- If the provisions of Community law and the Environmental Liability Directive must be interpreted as they prevent national legislation which allows the public authorities to establish liability for remedying the environmental damage to the person who owns and/or operates an undertaking on the contaminated site, without an assessment whether there is a causal link between the conduct of that person and the occurrence of the contamination or the subjective requirement of intent or negligence?

On March 9, 2010, the European Court of Justice decided as follows:

In case the Environmental Liability Directive does not apply either ratione temporis and/or ratione materiae, an environmental pollution case will be governed by national law. 
The Environmental Liability Directive does not prevent national legislation which allows the competent authority to operate on the presumption of a causal link between operators and the pollution found, including also diffuse pollution, based on the fact that the operators' installations are located close to the polluted area. Notwithstanding, based on the "polluter pays" principle, in order to presume such a causal link the authority must have evidence which may justify its presumption. This evidence may refer to the location of the operator's installation closed to the pollution found and to a similarity between the pollutants identified and the substances used by the operator in carrying out his activities.

The competent authority can impose measures for remedying environmental damage regardless of any fault of operators whose activities cause the environmental damage and they are provided by Annex III to the Environmental Liability Directive. In this respect, the competent authority must carry out a prior investigation into the origin of the pollution found and must also establish a causal link between the operators' activities and the pollution.

In the cases C-379/08 and C-380/08, combined on October 21, 2008, Tribunale amministrativo regionale della Sicilia referred the following questions to the European Court of Justice for a preliminary ruling:

- If the Environmental Liability Directive (respectively article 7 and Annex II) must be interpreted as it prevents national legislation which allows public authorities "to require that actions be taken concerning environmental matrices which are different from and go further than those originally chosen at the conclusion of an appropriate investigation carried out on a consultative basis, which have already been approved and put into effect and are being implemented"?

- If the Environmental Liability Directive (respectively article 7 and Annex II) must be interpreted as it prevents national legislation which allows public authorities "to impose such requirements on its own initiative, that is, without having assessed the sitespecific conditions, the costs of implementation of the measures in relation to the reasonably foreseeable benefits, the possible or probable collateral damage and adverse effects on public health and safety, and the necessary time scales for implementation"?

- If the Environmental Liability Directive (respectively article 7 and Annex II) must be interpreted as it prevents national legislation which allows public authorities "to impose such requirements on its own initiative as conditions for authorization for the lawful use of areas of land not directly affected by the decontamination measures, in so far as they have already been decontaminated or were not, in any event, polluted, and situated within the confines of the Priolo Site of National Interest"?

On the same date as of the above mentioned case, C378/08, the European Court of Justice decided as follows:
The competent authority is allowed to alter substantially measures for remedying environmental damage which were chosen at the conclusion of a procedure carried out on a consultative basis with the operators concerned and which have already implemented or begun to be put into effect. In this respect the authority:

- must hear the operators on whom such measures are imposed, excepting an urgent environmental situation which requires immediate action on the part of the competent authority;

- must invite the persons on whose land those measures are to be carried out to submit their observations and to consider them; and

- must take into account the criteria provided in Section 1.3.1. of Annex II to the Environmental Liability Directive and its decision must provide the grounds of its choice, and, if the case, the grounds justifying that there was no need for a detailed examination based on those criteria or that it was not possible to carry out such an examination.

The Environmental Liability Directive does not prevent national legislation which allows the competent authority to make the exercise by operators requested to take the environmental recovery measures of the right to use their land under the condition that they carry out the required works, although that land is not affected by those measures given that it has never been polluted or has already been decontaminated.

Such measure must be a justification of preventing a deterioration of the environment in the area where those measures are implemented or, based on the precautionary principle, of preventing the occurrence or resurgence of further environmental damage on the land which is adjacent to the whole shoreline subject to those remedial measures.

\section{RELEVANCE OF THE CASE LAW IN RELATION TO THE OBJECTIVE ENVIRONMENTAL LIABILITY}

In these three cases, for the first time, the European Court of Justice decided on the implementation of the Environmental Liability Directive.

The European Court of Justice ruled that a member state may only establish a weak causal link between operators' activities and the environmental damage in order to force payment.

In these cases, the liability of the company charged was established on the basis of a chemical used that was also found at the damaged site. Not only the refinery company but all actors who owned land at the site were ordered to pay for damages as well as for the preventative measure of constructing barriers to prevent chemicals from entering the sea.

In this context it is worth mentioning that in accordance with the Report from the European Commission to the Council, the European Parliament, the European Economic and Social Committee and the Committee of the Regions [7], based on article 14 paragraph 2 of the Environmental Liability Directive, the low number of this Directive cases may reflect the preventive effect that the Environmental Liability 
Directive is already having. Notwithstanding there is insufficient data to draw reliable conclusions on the effectiveness of the Environmental Liability Directive in terms of actual remediation of environmental damage.

Although there is not significant available information which could allow for an assessment about the effectiveness of the Environmental Liability Directive in remedying environmental damage, following the case law of the European Court of Justice herein referred to, it is expectable a more predictable and legally certain application of the Environmental Liability Directive criteria by competent authorities and operators when dealing with cases of damage under this Directive.

In relation to the liability mechanism, the measures taken in case of an imminent threat with an environmental damage or after the occurrence of an accident or incident that may produce an environmental damage should be considered, in order to avoid its production or to diminish its effects [8]. The decisions rendered by the European Court of Justice have great signification not only concerning the liability, but also in the application of the precaution principle, prevention and polluter pay principles.

"The precaution principle is the attitude which any person must adopt that makes a decision on an activity about which one may reasonably suppose to present a serious hazard for the health of the present and future generations or for the environment. These persons, especially the public authorities, must give priority to health and security imperatives on economic freedoms... and to reduce the risk to an acceptable risk for a bearable economic cost" [9].

The fundamental orientation of the precaution principle is at first sight enough simple and direct. If an activity threatens the environment or human health, precautions are imposed, even if this threat is not evidenced from the scientific point of view [10].

To a more close analysis, the principle is difficult to understand, not offering but a basis which must be improved in the national legal systems and at the European Union level.

However, there cannot be retained a prevention of any scientific innovation, by applying the precaution principle. Professors Kourilsky and Viney remind that ,there is no $a$ priori opposition between precaution and technological progress. The precaution principle invites to a reflection upon the conditions in which this progress is performed rather than to an inhibition of any innovation."

The difference between the prevention and precaution principles is based first of all on the risk knowledge degree. In case of the prevention principle, the concept of risk refers to those risks whose cause-effect relationship is known, while in case of the precaution principle, the risks are unknown.

Prevention involves both the risk evaluation to avoid the hazards, and the actions based on the knowledge of the present situation, to prevent environmental degradation.

This principle supposes actions against the causes that produce pollution or degradation and activities to limit the destructive or noxious effects for the environmental factors [11].
The case law of the European Court of Justice should be analyzed considering that the Environmental Liability Directive created two liability systems: (i) the objective liability system and (ii) the fault liability system. The Environmental Liability Directive provides that the liable party is the operator who carries out occupational activities.

Operators who carry out certain hazardous activities, as listed in Annex III of the Environmental Liability Directive, are strictly liable (without fault) for environmental damage affecting water, soil as well as those protecting species and protected natural habitats.

Operators carrying professional activities other than those listed in Appendix III are subject to the fault liability system, being liable for any damage they cause to nature, mainly when the imminent threat or damage concerns protected species and natural habitats.

The two liability systems differ mainly from three points of view: the operators involved, the type of liability and the category of environmental damage covered [12].

Certain activities are, under any circumstance, excluded from the Environmental Liability Directive's field of application: activities performed mainly in the interest of national defense or international security, activities whose sole purpose is to ensure protection against natural disasters and activities in the nuclear domain.

Operators may benefit directly from certain exceptions and defenses (for example force majeure, armed conflict, third party intervention) and defenses introduces following the transposition of the Environmental Liability Directive (for example permit defense, state of the art defense).

Should there be an imminent threat of environmental damage, the operators have to take preventive action, they must remedy the environmental damage once it has occurred and to bear the costs under the "polluter pays" principle. In some cases where operators fail to act so, or are not identifiable, or have invoked defenses, the competent authority may step in and carry out the necessary preventive or remedial measures.

Most procedural obligations in EC environmental law are not accompanied by any express provisions regulating the effect of non-compliance, and national courts will therefore normally have to seek recourse to the aim and the purpose of the obligation in order to determine whether the infringement requires non-application of the contested act.

According to article 6 paragraphs 3-4 of Directive 92/43/EC on the conservation of natural habitats and of wild fauna and flora [13] an environmental impact assessment revealing that a project will have significant adverse effect on the environment may only be granted for reasons of overriding public interest and if compensatory measures are taken.

Should a project be granted without an environmental impact assessment and without considering whether this is justified by overriding public interest, the failure to carry out an environmental impact assessment will lead to a material infringement of Directive $92 / 43 / \mathrm{EC}$ and the act is therefore illegal. 
Notwithstanding, even if an environmental impact assessment demonstrates that a certain project would have significant adverse effects on the environment, Directive $85 / 337 / \mathrm{EC}$ on the assessment of the effects of certain public and private projects on the environment [14] does not provide any prohibition for authorities from approving the project. Although the obligations provided by Directive 85/337/EC intend to ensure that authorities dispose of proper scientific grounds on which to base their decisions, they do not impose restrictions in respect of the subsequent decision-making. Article 2 paragraph 2 of Directive 85/337/EC nevertheless requires that an environmental impact assessment is carried out prior to the grant of a development consent in respect of projects which are likely to have significant adverse effect on the environment.

A common feature of environmental directives is that they often require the member states to draw up plans and programs, but the consequences attached to this obligation differ.

\section{CONCLUSIONS}

The judgments of the European Court of Justice in these cases are a useful guide to national authorities on the interpretation of the Environmental Liability Directive and their rights to impose remediation requirements on operators.

It is advisable that in the future the national courts will consider the presumption of a causal link between operators and the pollution found on account of the fact that the operators' installations are located close to the polluted area provided by the judgments of the European Court of Justice and will apply the objective environmental liability.

The European Court of Human Rights has clearly stated the human right to a healthy environment and required the state parties to the Convention to ensure its effectiveness, but has also left the states the option to choose the necessary measures to guarantee and/or limit it.

The best solution to respond to the present problems, with regard to the reduction and, finally, elimination of the negative impact of human activities upon the environment consists in the combination of techniques and instruments with preventive and precautionary character. It is necessary to grant all the support to the process of research and innovation, to find the best methods, means, mechanisms, techniques and instruments to approach the environment protection problem.

The enforcement deficit regarding EC environmental law on the national level resides in the form, drafting and substance of environmental legislation. It is important that the obligations of result, if not the forms and methods for attaining those results, are clearly and unconditionally defined [15].

The Community needs to adopt environmental legislation that accommodates effective enforcement as a discrete value to a much higher degree than currently is the case.

\section{ACKNOWLEDGMENT}

This paper was written within the Human Resources Project, Project type: Research project to stimulate the establishment of young independent research teams, PN II-RU code 129/2010, "The impact of the community norms over the actions of the public local authorities", contract no. 28/12.08.2010.

\section{REFERENCES}

[1] Craiova Ap. C., Civ. S. I, Dec. no. 322/2009, in: $\square$ The Bulletin of the Courts of Appeal no. 2/2009", (in Romanian) C. H. Beck Publishing House, Bucharest, Romania, 5, pp. 12-15.

[2] EC Directive, Directive 2004/35/CE on environmental liability with regard to the prevention and remedying of environmental damage, Official Journal of the European Communities, L 143/56, April 30, 2004, Brussels.

[3] Case C-378/08, Official Journal of the European Communities, C 113, May 01, 2010, Brussels.

[4] Government Emergency Ordinance no. 195/2005 regarding the environmental protection, published in Romanian Official Gazette, Part I, no. 1196 of December 30, 2005.

[5] ECHR, Lopez Ostra v. Spain, December 9, 1994, European Court of Human Rights, (in English), on line at: http://cmiskp.echr.coe.int/tkp197/view.asp?action=html\&d ocumentId=695782\&portal=hbkm\&source $=$ externalbydocn umber\&table=F69A27FD8FB86142BF01C1166DEA3986 $\underline{49}$

[6] ECHR, Tătar v. Romania, January 27, 2009, European Court of Human Rights, on line at: http://cmiskp.echr.coe.int/tkp197/view.asp?item=1\&portal $=$ hbkm\&action=html\&highlight=Tatar $\% 20 \% 7 \mathrm{C} \% 20$ Roma nia\%20\%7C\%2067021/01\&sessionid $=75436135 \&$ skin $=$ hu doc-en

[7] European Commission, Report from the European Commission to the Council, the European Parliament, the European Economic and Social Committee and the Committee of the Regions, under Article 14(2) of Environmental Liability Directive, October 12, 2010, Brussels, $\operatorname{COM}(2010) \quad 581$ final, 2.3, 5, http://ec.europa.eu/environment/legal/liability/pdf/com_201 0 0581.pdf

[8] C. Mareş, $\square$ Towards a General Legal Framework of an International Objective Environmental Liability", In: Recent Researches in Energy, Environment, Entrepreneurship, Innovation, International WSEAS Press, Lanzarote, Canary Islands, Spain, 2011, pp. 143-149; see also J. Cazala, $\square$ Le principe de précaution en droit international", Bibliothèque de l'Institut des Hautes Études Internationales de Paris, Anthemis Publishing House, L.G.D.J., 2006, p. 9 and the following.

[9] P. Kourilski, G. Viney, $\square$ Le principe de précaution”, Odile Jacob Publishing House, Paris, 2000, p. 216.

[10] M. Du $\square$ u, $\square$ Treaty of environmental law", C. H. Beck Publishing House, Bucharest, 2007, p. 511.

[11] N. Sadeleer, $\square$ Les principes du pollueur - payeur, de prévention et de précaution. Essai sur la gènese et la portée juridique de quelques principes du droit de l'environnement", Bruylant Publishing House, Bruxelles, 1999, pp. 106-135.

[12] C. Pirotte, in $\square$ Les responsabilités environnementales dans l'espace européen. Point de vue franco-belge", Bruylant Publishing House, Bruxelles, 2006, pp. 655-665; see also A. Kiss, J.-P. Beurier, $\square$ Droit international de l'environnement", Pedone Publishing House, Paris, 2004, pp. 460-461; P. Thieffry, $\square$ Droit de l'environnement de l'Union Européenne", $2^{\text {nd }}$ ed., Bruylant Publishing House, Bruxelles, 2011, pp. 791-830. 
[13] EC Directive, Directive 92/43/EC on the conservation of natural habitats and of wild fauna and flora, Official Journal of the European Communities, L 206, July 22, 1992, Brussels, pp. 7-50. "3. Any plan or project not directly connected with or necessary to the management of the site but likely to have a significant effect thereon, either individually or in combination with other plans or projects, shall be subject to appropriate assessment of its implications for the site in view of the site's conservation objectives. In the light of the conclusions of the assessment of the implications for the site and subject to the provisions of paragraph 4 , the competent national authorities shall agree to the plan or project only after having ascertained that it will not adversely affect the integrity of the site concerned and, if appropriate, after having obtained the opinion of the general public.

4. If, in spite of a negative assessment of the implications for the site and in the absence of alternative solutions, a plan or project must nevertheless be carried out for imperative reasons of overriding public interest, including those of a social or economic nature, the Member State shall take all compensatory measures necessary to ensure that the overall coherence of Natura 2000 is protected. It shall inform the Commission of the compensatory measures adopted."

[14] EC Directive, Directive 85/337/EC on the assessment of the effects of certain public and private projects on the environment, Official Journal of the European Communities, L 175, July 5, 1985, Brussels, pp. 40-48. "1. Member States shall adopt all measures necessary to ensure that, before consent is given, projects likely to have significant effects on the environment by virtue inter alia, of their nature, size or location are made subject to an assessment with regard to their effects."

[15] P. Wennerås, $\square$ The enforcement of EC environmental law", Oxford University Press, Oxford, 2007, pp. 309-325.

\section{Creative Commons Attribution License 4.0 (Attribution 4.0 International, CC BY 4.0)}

This article is published under the terms of the Creative Commons Attribution License 4.0

https://creativecommons.org/licenses/by/4.0/deed.en_US 